\title{
VARIABILITY OF AGRONOMICALLY IMPORTANT TRAITS IN SPRING WHEAT HYBRIDS OBTAINED BY MARKER-ASSISTED SELECTION FROM CROSSES OF WINTER WHEAT WITH SPRING WHEAT DONORS OF RESISTANCE GENES
}

\section{A.I. STASYUK, I.N. LEONOVA, E.A. SALINA}

Federal Research Center Institute of Cytology and Genetics SB RAS, Federal Agency of Scientific Organizations, 10, prosp. Akademika Lavrent'eva, Novosibirsk,630090 Russia, e-mail stasyuk@bionet.nsc.ru, leonova@bionet.nsc.ru (corresponding author), salina@bionet.nsc.ru

ORCID: Leonova I.N. orcid.org/0000-0002-6516-0545

The authors declare no conflict of interests

Acknowledgements:

Supported by Russian Science Foundation (grant № 16-16-00011)

Received March 17, 2017

\section{Abstract}

Spring wheat is the main cereal crop in the West Siberian region of Russia and occupies more than $40 \%$ of the acreage. The widening of the genetic diversity of this culture and the creation of new varieties with high productivity and resistance to environmental factors have always been a key problem of breeding. Winter wheat varieties which are characterized by a wide diversity of useful characters such as tolerance to abiotic stressors, productive tillers and yield can be used as a promising source of agronomically important traits. Despite the fact that the methodological approach to the introgression of the gene pool of winter wheat into the genome of spring wheat has been in use for a long time to increase the yield of spring varieties, at the moment there is little available information concerning the manifestation of valuable traits in offspring obtained from the winter and spring wheat hybridization. However, such results are important for assessing the combining ability of winter and spring wheat varieties and for the selection of potential parents by a complex of characters. For the identification of the winter and spring genotypes in the offspring resulting from the hybridization of winter and spring parents with the help of convenient breeding methods, a large sample size populations and a long period of cultivation of plant material are required. The application of MAS technologies and markers linked to the target loci can significantly decrease the time of development of new breeding lines. In creation of breeding lines resistant to leaf rust, the winter wheat varieties Filatovka and Biyskaya ozymaya, adapted for cultivation in the West Siberian region, were involved in a scheme of hybridization. Spring wheat introgression line 5366-180 (Triticum aestivum/T. timopheevii) и spring wheat cultivar Tulaikovskaya 10, containing genetic material of Thinopyrum intermedium were the donors of effective leaf rust resistance genes LrTt2 and Lr6Ai\#2. The aim of this work was to evaluate the diversity of spring wheat forms obtained from these crosses on economically important traits and analysis of the genotype influence on their manifestation. The plants differing in winter and spring habits were selected in $F_{2}$ progeny by means of allele-specific markers to the $V R N-1$ genes. To identify genotypes containing leaf rust resistance genes, a microsatellite marker Xbarc232 and primers MF2/MR1r2 and MF2/MR4 specific for T. timopheevii and Th. intermedium translocations, respectively, were used. As a result of hybridization of winter varieties with spring donors, $122 \mathrm{~F}_{2}$ plants were obtained, of which 30 homozygous spring plants with different allelic composition of $V R N-1$ genes were selected. Of these, 12 plants according to molecular data with $L r$-specific primers contained alien translocations. For the comparative analysis of agronomic traits, six $\mathrm{F}_{2}$ plants were used which possessed the same allelic composition of $V R N-1$ genes as in the initial spring donors but differed in the presence or absence of $L r$ genes. $\mathrm{F}_{3-4}$ families obtained by selfing of the corresponding $F_{2}$ plants were studied during two field seasons on the following traits: heading date, productive tillers, grain number per spike, grain weight per spike, and 1000grain weight. The results of heading date evaluation showed that, despite the same allelic composition of the $V R N-1$ genes, there was a significant difference in the heading date between $\mathrm{F}_{3-4}$ hybrids and spring donors. Depending on the year of the field evaluation, the differences were three to eight days, and it was found that the presence of alien genetic material does not affect this trait. Analysis of the productivity traits of $\mathrm{F}_{3-4}$ hybrids indicated that the main impact to the manifestation of the traits was made by environmental factors. A significant contribution of the genotype to the phenotypic manifestation of the traits grain number per spike and 1000-grain weight was detected in the hybrid 70-12 
containing the translocation from Th. intermedium. The obtained data demonstrated the effectiveness of MAS for the identification of homozygous genotypes with desired traits in the early breeding stages using small sample population. Agronomic trait variations observed in the $\mathrm{F}_{3-4}$ progenies allows to select breeding lines with the optimal expression of valuable traits for further breeding. tivity traits

Keywords: spring bread wheat, $V R N-1$ genes, $L r$ genes, marker-assisted selection, produc-

In Russia, spring soft wheat is one of the most common cereal crops. When searching for promising sources of valuable traits for spring wheat and their use in diverse hybridization schemes, the gene pool of winter wheat is interesting as a source material for the enrichment of spring forms. It is known that winter soft wheat is characterized by a wide variability in tolerance to abiotic factors, productive tillers, ear fertility and yield [1,2]. Winter wheat has been used to expand the range of spring varieties in the world breeding practice since ancient times [3, 4]. Soviet scientists applied winter and spring wheat crossings to study and select seeds by earing time [5,6]. It was shown that in $F_{2}$ and $F_{3}$ there were plants with an earlier earing as compared to the spring parent, but they had no tillering ability and had only one stalk.

Productive and drought-resistant spring wheat varieties were obtained by the hybridization of the winter varieties Bezostaya 1, Aurora, and the Caucasus with spring ones [7, 8]. At the International Maize and Wheat Improvement Center (CIMMYT), breeding lines and varieties of spring soft wheat with high yields, resistance to fungal diseases and a short stem have been created by the hybridization of winter and spring forms [9]. The spring wheat variety Extrakolben was obtained in Sweden by crossing a spring wheat variety with a winter one. Its yields are $10 \%$ higher than in the best initial varieties, indicating the possibility of significantly increasing productivity of spring varieties when crossing with winter forms [10]. By using the winter varieties Bezostaya 1, Myronivska 808, Early 12 as a maternal form and the spring variety Vardenik 9 as a pollinator, spring hybrid forms were received, exceeding the spring parent by 1000-grain weight [11]. In addition, constant lines with high productivity and good grain quality were identified among the hybrid generations.

The combinative ability $[12,13]$ and heterosis in hybrid wheat forms obtained by crossing varieties which differ in their mode of life have been reported [14-17]. However, we have little available information about economically important traits in the offspring of such crosses.

In recent years, marker-assisted selection (MAS) has been used in addition to traditional methods. Its main advantages include the identification of genotypes homozygous for the target trait by chromosome-specific markers and the ability to detect target genotypes on small samples [18].

To create a new selection material and transfer effective leaf rust diseases resistance genes into the genome of winter and spring soft wheat, we used a hybridization scheme where winter wheat varieties adapted for growth in the Western Siberian region were used as recipients. Spring forms containing alien genetic material with resistance genes inherited from Triticum timopheevii and Thinopyrum intermedium were donors $[19,20]$. Obtaining winter genotypes with molecular markers for identification of the genes controlling winter or spring mode of life and resistance to leaf rust diseases, and evaluating their winter hardiness and susceptibility to the pathogen have been described earlier [21]. This report presents the first results of study on spring offspring from crossing the winter and spring parents based on the sprouting period and harvesting components. Here, the effect of genetic material inherited from Triticum timopheevii and Thinopyrum intermedium on the manifestation of the traits is analyzed.

The aim of this work is to compare the productive properties of spring 
wheat hybrids with introgressed leaf rust resistance.

Technique. The winter soft wheat varieties Filatovka and Biyskaya ozymaya were used as maternal forms in hybridization. The spring introgressive line 5366-180 (T. aestivum/T. timopheevii), and the soft wheat variety Tulaikovskaya 10 (T. aestivum/Th. Intermedium) with leaf rust resistance genes LrTt2 and $L r 6 A i \# 2$, respectively, were the donors [19, 20]. Before the hybridization, the winter varieties were vernalized for 60 days at $3{ }^{\circ} \mathrm{C}$. Crossing with spring donors of resistance genes and growing of $F_{1}$ and $F_{2}$ hybrids were carried out in a hydroponic greenhouse (Center for Collective Use of Artificial Plants Growing Laboratory, FRC Institute of Cytology and Genetics).

The $\mathrm{F}_{2}$ plants obtained by hybridization were genotyped using allelespecific markers to $V R N-1$ genes and an alien genetic material containing $\mathrm{Lr}$ genes. Genomic DNA was isolated from the leaves of young plants using sodium bisulfite $\mathrm{Na}_{2} \mathrm{~S}_{2} \mathrm{O}_{5}$ as described [22]. Spring and winter plants were selected using markers to dominant and recessive alleles $V r n-A 1, V r n-B 1$ and $V r n-D 1$. To select plants carrying the LrTt2 gene from Triticum timopheevii, we used the SSR marker Xbarc232 [23]. To identify the Lr6Ai\#2 locus from Thinopyrum intermedi$u m$, we used the two pairs of primers, $M F 2 / M R 1 r 2$ and $M F 2 / M R 4$, developed by us [24]. The structure of the primer to $V R N-1$ genes, PCR protocol for the primers to the $V R N-1$ genes, MF2/MR1r2 and $M F 2 / M R 4$ [25], as well as the PCR protocol for the Xbarc232 marker [22] were described previously. PCR was performed on a Bio-Rad T-100 Thermal Cycler; the PCR product was separated in a $1.5 \%$ agarose gel with ethidium bromide and visualized using the gel documentation system Gel Doc XR+ (Bio-Rad, USA).

$\mathrm{F}_{3-4}$ from self-pollination of the spring plants $\mathrm{F}_{2}$, selected by molecular markers, were evaluated under field conditions in 2014 and 2016 (experimental field, Novosibirsk region, Krasnoobsk settlement) by the traits of the sproutingearing time, productive tillers, the grain number per spike, the grain weight per ear and the 1000-grain weight. Sowing (on May 14, 2014 and May 17, 2016) was carried out manually in 2 replicates (initial spring forms were the control). Plants were grown in $1 \mathrm{~m}$ plots in width, with 40-60 seedlings in a row with a distance between rows of $20 \mathrm{~cm}$. The sprouting-earing time was considered to be the time from the appearance of sprouts to the exit of the ear from the tube. The number of productive shoots was determined as the number of all lacustrine shoots of the plant. The 1000-grain weight was counted in 2-3 ears for 20 plants of each sample. For the statistical processing of remaining traits data, 25 plants were randomly selected.

In determining the reliability of the differences between the mean values of the two sample collections, Student's $t$-test was used. Samples were compared by variance factor analysis; reliability was assessed according to the Fisher $F$ criterion; the contribution of factors was calculated according to L.A. Vasilyeva [26]. The statistical processing was carried out using the Statistica 10.0 software package (StatSoft, Inc., USA). The tables and figures show the arithmetic mean $(x)$ and the mean error $\left( \pm s_{x}\right)$.

Results. The weather conditions during the vegetation period differed in the amount of precipitation and the temperature regime from year to year. In 2014, they were close to the average long-term, while in May there was a heat deficit and excessive moisture. In 2016, there was a decrease in moisture supply throughout the entire field season and higher temperatures as compared to 2014.

The winter soft wheat varieties Filatovka and Biyskaya ozymaya, adapted to the soil and climatic conditions of Western Siberia, have high winter hardiness, are highly productive, resistant to abiotic factors, but sensitive to most varieties of leaf rust [2]. In hybridization of the Filatovka and Biyskaya ozymaya va- 
rieties with the introgression line 5366-180 and Tulaikovskaya 10, 122 descendants were obtained, of which 30 homozygous spring plants with different allelic composition of $V R N-1$ genes were selected by molecular marking in $\mathrm{F}_{2}$. Of these, 12 plants contained alien translocations with $L r$ genes. As an example, an electrophoregram of PCR amplification products of the genomic DNA of parents and $\mathrm{F}_{2}$ progeny with SSR marker Xbarc232 is shown (Fig. 1). In the winter varieties Biyskaya ozymaya and Tulaikovskaya 10 with Xbarc232, a 200 bp fragment specific for the long arm of 5B chromosome was synthesized; and in the introgressive line 5366-180 and plant No. 6 from the $F_{2}$ population this fragment was absent (zero allele) that indicates the presence of alien translocation with the gene $\operatorname{LrTt} 2$.

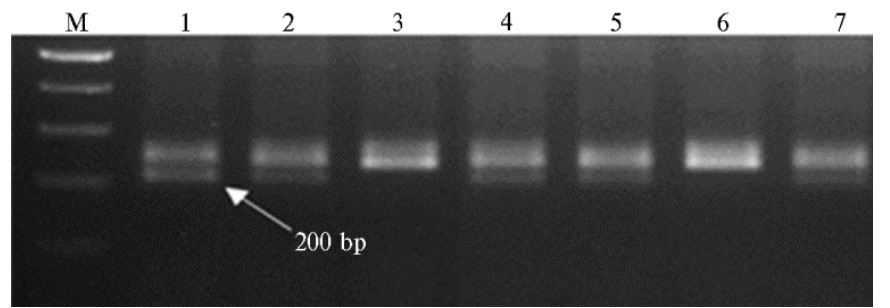

Fig. 1. Identification of genotypes with leaf rust resistance gene LrTt2 using the Xbarc232 DNA marker: 1 and 2 - the varieties Biyskaya ozymaya and Tulaikovskaya 10 , respectively; 3 - introgressive line 5366-180; 4-7 - the $\mathrm{F}_{2}$ plants; $\mathrm{M}$ - the

fragment length marker (100 bp ladder, Biosan, Novosibirsk). The arrow indicates a diagnostic $200 \mathrm{bp}$ fragment.

We compared economically valuable traits in six $F_{2}$ offspring plants that had the same allelic composition of $V R N-1$ genes as in the spring parent, but differed from it by the presence or absence of $L r$ genes (Table 1). Hybrids containing $L r$ genes according to the results of molecular analysis have low susceptibility to the West Siberian population of leaf rust (Puccinia triticina Erikss.) (data not shown).
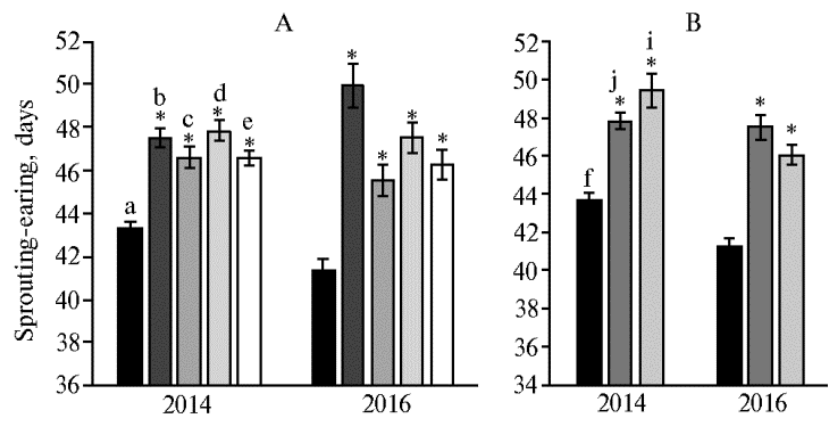

Fig. 2. Sprouting-earing in spring plants $\mathrm{F}_{3-4}$ from crossing Filatovka $\times$ 5366-180 (donor of gene LrTt2) (A) and Biyskaya ozymaya $\times$ Tulaikovskaya 10 (donor of Lr6Ai\#2 gene) (B) in different years, as compared to the parental forms: a $-5366-180$ (control), b, c, d, e - lines 90-7, 88-11, 883, 89-12, f - Tulaikovskaya 10 (control), g, i - lines 70-12, 7112 (experimental field, Novosibirsk region).

* Differences between hybrid lines and parental forms are statistically significant at $\mathrm{p}<0.001$.

It is known that the combination of dominant and recessive alleles of $V R N-1$ not only determines the type of development, but also affects the rate of development and the time of earing [27, 28]. There is also the assumption of an earlier earing and higher yielding in soft wheat varieties with two dominant genes $V r n-A 1$ and Vrn-B1 [29]. The evaluation of the earing time in the spring offspring $\mathrm{F}_{3-4}$, obtained by crossing winter varieties and spring resistant donors, showed that hybrid plants were eared much later than the spring parent (Fig. 2). Thus, for plants derived from crossing Filatovka $\times 5366-180$, the difference in earing onset compared to the spring parent was on average 3.3-4.5 days in 2014 and 4.2-8.6 days in 2016 (Fig. 2, A). It should be noted that there are no differences in the earing time in samples containing and not containing alien translocations with $L r$ genes. In the offspring from crossing varieties Biyskaya ozymaya and Tulaikovskaya 10 (see Fig. 2, B), the lines 70-12 and 71-12 were identical to 
the parent Tulaikovskaya 10 plants in $V R N-1$ alleles, but the line $70-12$ possessed introgression. The evaluation of the earing time showed a delay in earing onset in both lines compared to parent variety regardless of the year of field tests.

Grain number per spike in all studied Filatovka $\times 5366-180$ hybrids significantly increased in 2014, but in 2016, no differences were observed. In crossing Biyskaya ozymaya $\times$ Tulaikovskaya 10 , the sample $70-12$ with translocation from Th. intermedium significantly exceeded the original variety in both years, whereas the line 71-12 without translocation did not differ from the spring parent (Table 2). Grain weight per spike in the first combination significantly exceeded that in the control lines 90-7, 88-11 and 88-3 in 2014, and in the second combination the line 70-12 1.2 times exceeded the control in 2016. The 1000grain weight for the samples 88-11 and 88-3 in the progeny Filatovka $\times 5366-$ 180 was 35.7 and $35.1 \mathrm{~g}$, respectively, which is significantly lower than that for the line 5366-180 (38.2 g), and the samples 90-7 and 89-12 did not differ from the control. In 2016, no samples from the first combination showed significant differences from the control 1000-grain weight, and in the second combination, it was significantly lower in the line 70-12 in both years (Table 2).

2. Economically valuable characteristics of $F_{3-4}$ progeny and parental forms of spring soft wheat in different years for two hybrid combinations $\left(x \pm s_{x}\right.$, experimental field, Novosibirsk region)

\begin{tabular}{|c|c|c|c|}
\hline Sample, variety, line & Traits & 2014 & 2016 \\
\hline & Filatovka $\times 530$ & & \\
\hline \multirow[t]{4}{*}{ 5366-180 (control) } & Productive tillers, pcs. & $2.50 \pm 0.14$ & $3.13 \pm 0.21$ \\
\hline & Grain number per spike, pcs. & $28.79 \pm 0.71$ & $23.45 \pm 1.21$ \\
\hline & Grain weight per spike, $\mathrm{g}$ & $1.15 \pm 0.04$ & $0.64 \pm 0.04$ \\
\hline & 1000 -grain weight, g & $38.15 \pm 0.60$ & $25.79 \pm 0.79$ \\
\hline \multirow[t]{4}{*}{$90-7$} & Productive tillers, pcs. & $3.23 \pm 0.21^{* *}$ & $2.31 \pm 0.26^{*}$ \\
\hline & Grain number per spike, pcs. & $32.74 \pm 1.23^{*}$ & $25.58 \pm 2.22$ \\
\hline & Grain weight per spike, $\mathrm{g}$ & $1.32 \pm 0.06^{*}$ & $0.65 \pm 0.07$ \\
\hline & 1000-grain weight, g & $36.64 \pm 0.57$ & $24.17 \pm 1.58$ \\
\hline \multirow[t]{4}{*}{$88-11$} & Productive tillers, pcs. & $2.46 \pm 0.19$ & $2.60 \pm 0.23$ \\
\hline & Grain number per spike, pcs. & $36.40 \pm 1.52 * * *$ & $26.50 \pm 1.45$ \\
\hline & Grain weight per spike, $\mathrm{g}$ & $1.38 \pm 0.07 * *$ & $0.70 \pm 0.04$ \\
\hline & 1000 -grain weight $\mathrm{g}$ & $35.65 \pm 0.70^{* *}$ & $25.63 \pm 0.72$ \\
\hline \multirow[t]{4}{*}{$88-3$} & Productive tillers, pcs. & $2.64 \pm 0.17$ & $2.17 \pm 0.25^{* *}$ \\
\hline & Grain number per spike, pcs. & $36.03 \pm 1.34 * * *$ & $20.27 \pm 1.69$ \\
\hline & Grain weight per spike, $\mathrm{g}$ & $1.37 \pm 0.06^{* *}$ & $0.55 \pm 0.06$ \\
\hline & 1000 -grain weight, $\mathrm{g}$ & $35.09 \pm 0.72 * *$ & $24.34 \pm 1.14$ \\
\hline \multirow[t]{5}{*}{$89-12$} & Productive tillers, pcs. & $2.41 \pm 0.15$ & $2.68 \pm 0.36$ \\
\hline & Grain number per spike, pcs. & $31.59 \pm 1.16^{*}$ & $22.06 \pm 1.83$ \\
\hline & Grain weight per spike $g$ & $1.26 \pm 0.06$ & $0.61 \pm 0.06$ \\
\hline & 1000-grain weight, g & $36.93 \pm 0.93$ & $26.15 \pm 1.25$ \\
\hline & Biyskaya ozymaya $\times$ Tul & o s k a y a 10 & \\
\hline \multirow[t]{4}{*}{ Tulaikovskaya 10 (control) } & Productive tillers, pcs. & $2.28 \pm 0.13$ & $2.71 \pm 0.17$ \\
\hline & Grain number per spike, pcs. & $33.52 \pm 1.14$ & $28.98 \pm 1.30$ \\
\hline & Grain weight per spike, g & $1.18 \pm 0.05$ & $0.87 \pm 0.04$ \\
\hline & 1000 -grain weight, $\mathrm{g}$ & $33.93 \pm 0.57$ & $28.96 \pm 0.58$ \\
\hline \multirow[t]{4}{*}{$70-12$} & Productive tillers, pcs. & $2.03 \pm 0.22$ & $1.64 \pm 0.16^{* * *}$ \\
\hline & Number of grains in the ear, pcs. & $41.19 \pm 2.39 * *$ & $38.94 \pm 1.93^{* * *}$ \\
\hline & Grain weight per spike, $\mathrm{g}$ & $1.33 \pm 0.12$ & $1.04 \pm 0.08 *$ \\
\hline & 1000-grain weight, g & $29.22 \pm 1.30^{* * *}$ & $26.48 \pm 1.08 *$ \\
\hline \multirow[t]{4}{*}{$71-12$} & Productive tillers, pcs. & $2.27 \pm 0.19$ & $2.19 \pm 0.20^{*}$ \\
\hline & Grain number per spike, pcs. & $35.22 \pm 2.11$ & $32.30 \pm 1.62$ \\
\hline & Grain weight per spike, g & $1.21 \pm 0.09$ & $0.79 \pm 0.06$ \\
\hline & 1000 -grain weight, $\mathrm{g}$ & $32.68 \pm 1.02$ & $23.27 \pm 0.99 * * *$ \\
\hline
\end{tabular}

It should be noted that almost all of the samples, including parents, had quantitative indicators declining in 2016, which may be due to weather conditions. The significant influence of environmental factors on quantitative indicators was also supported by the factor analysis (Table 3 ).

The factor variance analysis, based on the evaluation of economically important traits, showed that the genotype of hybrid lines contributed significantly to 
sprouting-earing time while productive tillering depended only on environmental conditions (see Table 3).

3. Factor analysis of variance based on economically valuable characteristics of $F_{3-4}$ progeny and parental forms of spring soft wheat for two hybrids combinations (experimental field, Novosibirsk Region, 2014 and 2016)

\begin{tabular}{|c|c|c|c|c|c|c|c|c|}
\hline \multirow{3}{*}{ Traits } & \multicolumn{4}{|c|}{ Filatovka $\times 5366-180$} & \multicolumn{4}{|c|}{ Biyskaya ozymaya $\times$ Tulaikovskaya 10} \\
\hline & \multicolumn{2}{|c|}{ introgression } & \multicolumn{2}{|c|}{ no introgression } & \multicolumn{2}{|c|}{ introgression } & \multicolumn{2}{|c|}{ no introgression } \\
\hline & $r_{\mathrm{wg}}$ & $r_{w e}$ & $r_{w g}$ & $\mathrm{r}_{\mathrm{we}}$ & $\mathrm{r}_{\mathrm{wg}}$ & $r_{w e}$ & $\mathrm{r}_{\mathrm{wg}}$ & $\mathrm{r}_{\mathrm{we}}$ \\
\hline Sprou & $0.94 * * * * *$ & 0.05 & $97.1^{* * * * *}$ & 2.70 & $0.91^{* * * * *}$ & 0.08 & $0.99^{* * * * *}$ & 0.01 \\
\hline Proc & 1 & $0.98^{* * * * * *}$ & 0.05 & $0.92^{* * * * *}$ & 0.12 & $0.86^{* * * *}$ & 0.01 & $0.98^{* *}$ \\
\hline & $2 * *$ & 0.7 & 0.09 & $0.78^{* *}$ & $0.83^{* * * *}$ & 0.1 & 0.23 & 0. \\
\hline Gra & 5 & $0.92 *$ & 0.04 & $.93^{*}$ & 0.20 & $0.80^{* * *}$ & 0.03 & $0.95^{* *}$ \\
\hline 1000 & 0.02 & $0.96^{* * *}$ & 0.02 & $0.98^{* * *}$ & $0.55^{* * *}$ & $0.41^{*}$ & 0.26 & $0.68^{* *}$ \\
\hline \multicolumn{9}{|c|}{$\begin{array}{l}\mathrm{N} \text { ot e }, \mathrm{r}_{\mathrm{wg}} \text { and } \mathrm{r}_{\mathrm{we}}-\text { correlation coefficients determining the contribution of the genotype and the environment } \\
\text { respectively to the trait phenotypic manifestation. } \\
*^{* * * * * *}, * * * *, * * * * * \text { The influence of the genotype and the external environment is statistically significant at } \\
\mathrm{p}<0.05, \mathrm{p}<0.01, \mathrm{p}<0.001, \mathrm{p}<0.0001 \text { and } \mathrm{p}<0.00001 \text {. }\end{array}$} \\
\hline
\end{tabular}

The factor analysis suggests that the translocations do not affect sprouting-earing time and productive tillering in the hybrids. However, in the sample 70-12 from Biyskaya ozymaya $\times$ Tulaikovskaya 10 crossing, the grain number per spike and the 1000-grain weight are more influenced by the genotype, whereas in the sample 71-12 these are mainly influences by the environmental conditions. It is not excluded that the trait variability in these hybrids is due to the influence of the alien genetic material, since the line 70-12 contains a translocation from $T h$. intermedium.

In all the studied spring lines selected from crossing with winter varieties the earing delayed as compared to the spring parent, regardless of their haplotype by the $V R N-1$ genes and the presence of alien translocations. It should be noted that at the beginning of the 20th century the attempts to obtain earlier spring samples from the crossing of spring and winter wheat varieties were unsuccessful [3-6]. First, spring character is ensured by dominant $V R N-1$ gene, but the earing depends on the interaction of many regulatory and structural genes, which can be introduced from the winter genotype [30, 31]. In addition, variations were observed within the lines both for earing time and other economically important traits (see Fig. 2, Table 2), which makes it possible to select spring forms of plants that are superior to the parent forms in productivity and close to them in earing onset. We cannot exclude that when using winter varieties from the European region in crossings with spring wheat, the delay in earing of the spring progeny can be much less.

Thus, our results testify to the effectiveness of allele-specific markers in the selection of genotypes by target loci. The genotyping of samples simultaneously by several genetic loci can significantly reduce the sample size and allows to identify the homozygous offspring in $F_{2}$ population. Considerable delay in earing in the spring offsprings, obtained by hybridization of winter and spring soft wheat, is apparently not related to the effect of $V R N-1$ genes which determine the timing of earing. The evaluation of the $\mathrm{F}_{3-4}$ spring families by quantitative characteristics did not reveal reliable differences from the parental forms. Field study of the samples during two seasons showed that the environmental factors mainly contribute to the manifestation of these characteristics. The sample 70-12, in which the significant influence of the genotype on the manifestation of quantitative traits can be explained by the presence of alien genetic material, is an exception.

\section{REFERENCES}

1. Sharma S., Chaudhary H.K. Combining ability and gene action studies for yield contributing traits in crosses involving winter and spring wheat genotypes. Acta Agron. Hungarica, 
2009, 57: 417-423 (doi: 10.1556/AAgr.57.2009.4.4).

2. K o z lo v V.E. Vavilovskii zhurnal genetiki i selektsii, 2013, 17(3): 541-557 (in Russ.).

3. Nilsson-Ehle H. Selection of spring wheat in Sweden. Sveriges Utsadesforenings Tidskrift, Malmo, 1917, 28: 51-76 (Cited by Vavilov N.I. Nauchnye osnovy selektsii pshenitsy. M., 1935).

4. M ish ra C.N., Venkat e sh K., Ku ma r S., Singh S.K., Tiwari V., S harma I. Harnessing winter wheat variability for enhancement of yield in spring wheat. International Journal of Bio-resource and Stress Management, 2013, 4(2 special): 375-377.

5. Vavilov N.I., K u z n t s o v E.S. Izvestiya agronomicheskogo fakul'teta Saratovskogo universitetata, 1921, 1: 1-25 (in Russ.).

6. Lysenko T.D., Prezent I.I. Selektsiya i teoriya stadiinogo razvitiya rasteniya [Selection and a concept of step-by-step development in plants]. Moscow, 1935 (in Russ.).

7. Luk'y a ne nko P.P. Selektsiya $i$ semenovodstvo ozimoi pshenitsy. Izbrannye trudy [Winter wheat breeding and seed production. Selected works]. Moscow, 1973 (in Russ.).

8. Dorofeev V.F., Udachin R.A., Semenova L.V., Novikova M.V., Gradchaninova O.D., Shitova I.P., Merezhko A.F., Filatenko A.A. Pshenitsy mira [Wheats]. Leningrad, 1987 (in Russ.).

9. Rajaram S., B orlaug N.E., va n Ginkel M. CIMMYT international wheat breeding. In: Bread wheat: improvement and production. B.C. Curtis, S. Rajaram, G.H. Macpherson (eds.). FAO, Rome, 2002.

10. Vavilov N.I. Nauchnye osnovy selektsii pshenitsy [Fundamentals for wheat breeding]. Moscow, 1935 (in Russ.).

11. Nik og os y a n E.E., S a f a ry a n G.E. Biologicheskii zhurnal Armenii, 1977, XXX(9): 80-85 (in Russ.).

12. Kant L., Mahajan V., Gupta H.S., Pandey M.C. Winter $\times$ spring wheat hybridization: a potential source for yield advancement. International Journal of Plant Breeding, 2008, 2(2): 69-73.

13. Kapoor E., Mondal S.K., Dey T. Combining ability analysis for yield and yield contributing traits in winter and spring wheat combinations. Journal of Wheat Research, 2011, 3(1): 52-58.

14. Rutts R.I., Le o nt'ev S.I. Nauchnye trudy Omskogo sel'skokhozyaistvennogo instituta im. S.M. Kirova, 1967, 69(4): 75-82 (in Russ.).

15. Grant M.N., M $\mathrm{cKe} n \mathrm{zi}$ e H. Heterosis in $\mathrm{F}_{1}$ hybrids between spring and winter wheat. Can. J. Plant Sci., 1970, 50: 137-140.

16. B a ri c M., S a r c e vi c H., Ke re s a S. Analysis of yield components of $\mathrm{F}_{1}$ hybrids of crosses between spring and winter types (Triticum aestivum L.). Agriculturae Conspectus Scientificus, 2004, 69(1): 11-15.

17. Mo is e nko L.M., Klykov A.G., Konovalova I.V., Bogda n P.M. Dostizheniya nauki i tekhniki APK, 2011, 12: 28-30 (in Russ.).

18. L e o n o va I.N. Molecular markers: Implementation in crop plant breeding for identification, introgression and gene pyramiding. Rus. J. Genetics: Applied Research, 2013, 3(6): 464-473 (doi: 10.1134/S2079059713060051).

19. Timonova E.M., Leo nova I.N., Röder M.S., Salina E.A. Marker-assisted development and characterization of a set of Triticum aestivum lines carrying different introgressions from the T. timopheevii genome. Mol. Breed., 2013, 31: 123-136 (doi: 10.1007/s11032-012-9776-x).

20. Salina E.A., Adonina I.G., Badaeva E.D., Kroupin P.Yu., Stas yuk A.I., Leonova I.N., Shishkina A.A., Divashuk M.G., Starikova E.V., Khuat T.M.L., S y u k ov V.V., Karlov G.I. A Thinopyrum intermedium chromosome in bread wheat cultivars as a source of genes conferring resistance to fungal diseases. Euphytica, 2015, 204: 91-101 (doi: 10.1007/s10681-014-1344-5).

21. Stasyuk A.I., Le o nova I.N., Shcherban' A.B., Salina E.A. Mat. 2-i Mezhd. Konf. "Genofond $i$ selektsiya rastenii» [Proc. 2 ${ }^{\text {nd }}$ Int. Conf. "Gene pool and plant breeding»]. Novosibirsk, 2016: 59.

22. K is e leva A.A., Shcherban A.B., Leonova I.N., Frenkel Z., S a lina E.A. Identification of new heading date determinants in wheat 5B chromosome. BMC Plant Biol., 2016, 16(Suppl 1): 8 (doi: 10.1186/s12870-015-0688-x).

23. Song Q.J., Shi J.R., S ingh S., Fickus E.W., Costa J.M., Le wis J., Gill B.S., W a rd R., C regan P.B. Development and mapping of microsatellite (SSR) markers in wheat. Theor. Appl. Genet., 2005, 110: 550-560 (doi: 10.1007/s00122-004-1871-x).

24. S a li na E.A., L e o nova I.N., S h c h e rb a n' A.B., S t a s y u A.I. Sposob sozdaniya linii ozimoi myagkoi pshenitsei s kompleksnoi ustoichivost'yu $k$ buroi i steblevoi rzhavchine $i$ muchnistoi rose. Federal'nyi issledovatel'skii tsentr Institut tsitologii i genetiki SO RAN (RF). Patent RF № 2598275 ot 20.09.2016 [Method of creating winter soft wheat lines with complex resistance to brown and stem rust and powdery mildew. Institute of Cytology and Genetics SB RAS (RF). Patent № 2598275 of 20.09.2016]. Appl. 29.07.2015. Publ. 30.08.2016 (in Russ.).

25. Likhenko I.E., Stasyuk A.I., Shcherban' A.B., Zyryanova A.F., Likhen - 
ko N.I., S a li na E.A. Vavilovskii zhurnal genetiki $i$ selektsii, 2014, 18(4/1): 691-703 (in Russ.).

26. V a s i l'e v a L.A. Statisticheskie metody $v$ biologii [Statistical methods in biology]. Novosibirsk, 2004 (in Russ.)

27. S t e l' $\mathrm{m}$ a k h A.F. Selektsiya i semenovodstvo, 1981, 48: 8-15 (in Russ.).

28. Trevaskis B., He m ming M.N., D e $n \mathrm{n}$ is E.S., P e a c o ck W.J. The molecular basis of vernalization-induced flowering in cereals. Trends in Plant Science, 2007, 12(8): 352-357 (doi: 10.1016/j.tplants.2007.06.010).

29. Fait V.I., Stel'makh A.F. Sibirskii vestnik sel'skokhozyaistvennoi nauki, 1993, 2: 32-41 (in Russ.).

30. Chen A., Li C., Hu W., Lau M.Y., Lin H., Rockwell N.C., Martinc S.S., J e rnstedt J.A., Lagari as c J.C., Dubcovsky J. Phytochrome C plays a major role in the acceleration of wheat flowering under long-day photoperiod. PNAS USA, 2014, 111: 1003710044 (doi: 10.1073/pnas.1409795111).

31. Pearce S., Kippes N., Chen A., Debernardi J.M., Dubcovsky J. RNA-seq studies using wheat phytochrome $\mathrm{B}$ and phytochrome $\mathrm{C}$ mutants reveal shared and specific functions in the regulation of flowering and shade-avoidance pathways. BMC Plant. Biol., 2016, 16: 141 (doi: 10.1186/s12870-016-0831-3). 